\title{
Effects of protein concentrate supplementation-based diet on growth and nutritional status in dairy heifers
}

\author{
Md. Shakil Islam, Md. Rezwanul Habib, Mohammad Ashiqul Islam and ${ }^{\bowtie}$ Md. Harun-ur-Rashid \\ Department of Dairy Science, Bangladesh Agricultural University, Mymensingh-2202, Bangladesh
}

\begin{tabular}{l}
\hline ARTICLE INFO OPENAAccess \\
\hline Article history: \\
Received : 05 November 2018 \\
Accepted : 05 March 2019 \\
Published: 31 March 2019 \\
\hline Keywords: \\
Soybean meal, mustard oil cake, \\
growth, blood serum and heifers \\
\hline Correspondence: \\
Md. Harun-ur-Rashid \\
囚: mrashid_69@yahoo.com
\end{tabular}

Copyright:

(C2019 by authors and BAURES. This work is licensed under the Creative Commons Attribution International License (CC By 4.0).

\section{Introduction}

Heifer rearing is a major portion of dairy herd turnover and farmers want to rear heifers for entering into the herd at optimum weight and age to acquire the best production and fertility achievement (Tegasc, 2014). Grazing forage or green grass may be the source of heifer feed but it is not well balanced until supply of concentrate mixture and minerals along these. Concentrate mixture should have high density of energy and nitrogen which will be the best useful way to gain maximum output from heifers (Wanapat, 1999). Addition of nutrient rich ingredients in the concentrate mixture depends on types of basal diet (Doyle et al., 2008). Soybean meal (Glycine max) and mustard oil cake (Brassica napus) are well known protein source ingredients for ruminant feeding. Attributes of soybean meal makes it more acceptable to the animal as feed (Baker, 2000). Again, crude protein content of mustard oil cake (MOC) varies from 33-40\%; of which $80-83 \%$ is true protein with appreciable proportion of albumin, glutelin and globulin. Also, MOC is rich in lysine and sulphur containing amino acids (Klockeman, 1997). It has been scientifically proved that addition of fish meal in the concentrate mixture improve the reproductive performance of heifer (Alam et al., 2012). Monitoring of nutritional status of the animal are vital because these are the indicators of health status (Ate et al., 2009); and used for measuring energy and protein status. These indicators also used as an adjunct to other measures such as body weight and body condition score that reflect the integrated effects of nutrition over time (Hammond, 1997).

Again, farmers of tropical countries provide large amount of lower grade roughage as basal feed to their livestock (Seresinhe and Pathirana, 2008) but heifer don't get enough nutrients through this type of roughage to improve her reproduction (Peripolli et al., 2016). Along with concentrate mixture and non-leguminous fodder in diet partial legume hay could be a good source of nitrogen for improving reproductive performance (Habib et al., 2018). It has been assumed that supply of protein rich ingredients to the heifer of tropical areas may have important potential because it improves forage digestibility and energy utilization through increasing the amino acid supply for the animal (Gilbery et al., 2006). Very recently Prima et al. (2018) carried out a research work on pre- and post-partum concentrate supplementation to crossbred cow and found significant changes in milk yield, milk protein and post-partum heat period. In our countries, heifers supplied with small amount of or almost no concentrate feed and if supplied but not nutritionally balanced. Thus, animals are being physiologically challenged which interfere with 
reproductive functions ultimately affects the profitability of the dairy farm. Hence, supplementation of protein rich ingredients in the diet of heifer is essential along with the supply of adequate amount of green grass. Owing to the aforesaid circumstances, it is essential to monitor the changes of dry matter intake, growth performances as well as blood serum nutrients of heifers in response to protein supplementation. The objective of this research was to observe the effect of feeding protein rich ingredients along with concentrate mixture on the growth and nutritional status of the dairy heifers.

\section{Materials and Methods}

\section{Animal management and diets}

Animal procedures were conducted at the Dairy Farm, Department of Dairy Science, Bangladesh Agricultural University, Mymensingh-2202, Bangladesh. Six (06) crossbred heifers (50\% Sahiwal, ShX; and 50\% Holstein Friesian, HFX) whose aged above 2 years were divided into two groups like control and supplemented; and the average live weight of each group was $150 \pm 5 \mathrm{~kg}$. The study was conducted for a period of 100 days of which first 10 days were for diet adjustment. Each heifer was kept in a face-out stanchion barn with individual manger and water trough. The basal diet consists of para grass (Brachiaria mutica) and german grass (Echinochloa crus-galli) which were supplied at 50:50 (18 kg/hd/d). Mixed concentrate $(1.9 \mathrm{~kg} / \mathrm{hd} / \mathrm{d})$ was offered to the heifers twice daily. Concentrate ingredients in control diet included rice polish, wheat bran, DCP and common salt. In addition to these, mustard oil cake and soybean meal were supplied to the supplemented group. Dry matter was offered @ 3.5\% of the live weight. Concentrate was fed prior to the green grass at 08:00 am and at 13:00 pm. Proximate composition of each ingredients were determined as described by AOAC (2000). Feed ingredients and chemical constituents of both control and protein supplemented diets are given in Table 1.

\section{Estimation of DMI and growth measurement}

DM intake $(\mathrm{kg})$ calculated from supplied feed and daily leftover. Body weight, body length, heart-girth and wither height of the experimental heifers were measured through weighing balance, measuring tape and wooden scale, respectively. Data for these variables were recorded on each heifer at fifteen days interval.

\section{Collection of blood and serum analysis}

About $10 \mathrm{~mL}$ blood was collected at 30 days intervals from jugular vein of each experimental heifer and kept in a tube (without anticoagulant). Then collected blood was allowed to clot at room temperature for a period of time (40-45 minutes). Thereafter, centrifugation was done using centrifuge (EBA 21 Hettich Zentrifugen, Germany) at $3000 \mathrm{rpm}$ for $15 \mathrm{~min}$. Following these, serum was harvested and kept in kitchen freezer until assayed.
Table 1. Ingredient and nutrient composition of the diet

\begin{tabular}{lcc}
\hline & \multicolumn{2}{c}{ Dietary groups } \\
\cline { 2 - 3 } & Control & Supplemented \\
\hline Ingredient composition $\left(\mathrm{g} \mathrm{kg}^{-1} \mathrm{DM}\right)$ & \\
Green grass & & \\
Para grass & 280.00 & 280.00 \\
German grass & 380.00 & 380.00 \\
Concentrate mixture & & \\
Rice polish & 180.00 & 150.00 \\
Wheat bran & 152.00 & 100.00 \\
Mustard oil cake & - & 50.00 \\
Soybean meal & - & 32.00 \\
DCP & 4.00 & 4.00 \\
Common salt & 4.00 & 4.00 \\
Chemical composition $\left(\mathrm{g} \mathrm{kg}^{-1} \mathrm{DM}\right)$ & \\
Dry matter & 435.20 & 432.60 \\
Crude protein & 102.57 & 120.45 \\
Crude fibre & 229.50 & 228.90 \\
Ether extract & 45.28 & 47.50 \\
Nitrogen-free-extract & 400.70 & 487.60 \\
Ash & 99.86 & 98.66 \\
ME (MJ kg & & \\
\hline
\end{tabular}

$\dagger$ Metabolizable energy (ME) values estimated according to the equation of Kearl (1982).

$\mathrm{ME}(\mathrm{MJ} / \mathrm{kg} \mathrm{DM})=[-0.45+(0.04453 \times \% \mathrm{TDN})] \times 4.184$

TDN is estimated according to the following equations:

TDN for roughages $(\%$ of DM $)=-17.2649+1.2120(\% \mathrm{CP})+0.8352$ $(\% \mathrm{NFE})+2.4637(\% \mathrm{EE})+0.4475(\% \mathrm{CF})$

TDN for concentrate $(\%$ of DM $)=40.3227+0.5398(\% \mathrm{CP})+0.4448$ $(\% \mathrm{NFE})+1.4218(\% \mathrm{EE})-0.7007$ (\%CF)

Glucose level in blood serum was measured through glucose oxidase and peroxidase method using enzymatic quantitative colorimetric kit (Vitro Scient, Egypt). Quantitative colorimetric kits albumin (Vivia-Biotech., Spain) and urea-LQ (Chemelex, Spain) were used to measure blood serum albumin and urea concentrations, respectively. The factor 2.14 was used to obtain the concentration of blood urea. URIT-810 chemistry analyser (URIT Medical Electronic Company Limited, China) was used as at 550,630 and $340 \mathrm{~nm}$ wavelengths to measure the serum glucose, albumin and urea, respectively.

\section{Statistical analysis}

Repeated Measures Analysis of Variance (RMANOVA) in Completely Randomized Design was executed to scrutinize the impacts of protein rich ingredients feeding to the dairy heifers on DMI, growth performance and blood serum nutrients. In this analysis, experimental heifer's initial body weight was not thought as a covariate because of non-significant influence on the dependent variables. Again, period of time was treated in the within-subjects factor to measure the parameters recurrently on the experimental units; whereas, dietary groups (independent variable) were subjected in between-subjects factor. 


\section{Results and Discussion}

\section{Dry matter intake and growth measurements}

Relevant data on between subjects and within subject effects are presented in Table 2 and 3, respectively. About 23\% higher $(\mathrm{P}=0.001) \mathrm{DMI}$ was found in protein supplemented group than that of the control group. It has been noticeable that time period has significant $(\mathrm{P}=0.01)$ impact on DMI whereas, interaction effect of both time and diet also significantly $(\mathrm{P}=0.01)$ influences on $\mathrm{DMI}$ of heifer. This trend of raising DMI are similar to Khandaker et al. (2012) who explained that addition of mustard oil cake makes the rice straw softer by disrupting the plant cell wall components. Similarly, Lanyi (1988) revealed that DMI of heifers increased by consumption of protein rich ingredients in diet. Again, DMI may increase significantly by the animal when protein levels in diet are raised from below the requirement to the optimum levels.

Table 2. Dietary effects on DM intake, growth performance and nutritional status of heifers

\begin{tabular}{|c|c|c|c|c|}
\hline \multirow[t]{2}{*}{ Parameters } & \multicolumn{2}{|c|}{ Dietary groups } & \multirow{2}{*}{$\begin{array}{c}\text { SEM } \\
( \pm)\end{array}$} & \multirow[t]{2}{*}{ P-value } \\
\hline & $\begin{array}{c}\text { Control } \\
(\mathbf{n}=3)\end{array}$ & $\begin{array}{c}\text { Supplemente } \\
\mathbf{d}(\mathrm{n}=3)\end{array}$ & & \\
\hline \multicolumn{5}{|c|}{ DM intake and growth performance } \\
\hline $\mathrm{DMI}\left(\mathrm{kg}^{-1} \mathrm{~d}\right)$ & 4.423 & 5.433 & 0.04 & 0.001 \\
\hline BWG (kg/15d) & 4.533 & 5.267 & 0.29 & 0.149 \\
\hline WHG (cm/15d) & 0.519 & 0.643 & 0.02 & 0.01 \\
\hline BLG $(\mathrm{cm} / 15 \mathrm{~d})$ & 1.234 & 1.977 & 0.07 & 0.002 \\
\hline $\operatorname{HGG}(\mathrm{cm} / 15 \mathrm{~d})$ & 1.133 & 1.400 & 0.05 & 0.016 \\
\hline \multicolumn{5}{|c|}{ Nutritional status parameters } \\
\hline Glucose (mmol/L) & 2.895 & 2.825 & 0.06 & 0.493 \\
\hline Albumin (g/dL) & 3.676 & 4.117 & 0.40 & 0.479 \\
\hline Urea (mg/dL) & 19.701 & 28.050 & 1.45 & 0.015 \\
\hline $\begin{array}{l}\text { Blood urea nitrogen } \\
(\mathrm{mg} / \mathrm{dL})\end{array}$ & 9.20 & 13.10 & 0.67 & 0.015 \\
\hline
\end{tabular}

SEM, standard error of the mean; DMI, dry matter intake; BWG, body weight gain; WHG, wither height gain; BLG, body length gain; HGG, heart-girth gain.

Body weight gain of the heifers non-significantly $(\mathrm{P}=0.149)$ influenced by the control and protein supplemented diet (Table 2). Probable causes of this insignificant difference might be increasing little percentages of protein rich ingredients in diet and another cause may be the heifers reached maximum growth stage of their life before starting the research trial. It has been literally proved by Wiltbank et al. (1966) that growth of the animals after reaching certain age did not increase in significant trend. By the way, it can be found from Table 3 that there existed a significant $(\mathrm{P}=0.01)$ time influence on $\mathrm{BWG}$ of heifers and interaction impact of both time and diet has also significant $(\mathrm{P}=0.05)$ on BWG. However, Divya and Anil-kumar (2009) concluded that significantly higher BWG found in those heifers received good plane of nutrition compared to the grass based diets. Live weight gain of heifers improved by concentrate and green grass feeding along with hay supplementation (Al-Shami, 2007).
Wither height gain (WHG), body length gain (BLG) and heart-girth gain (HGG) of the heifers obtained significantly $(\mathrm{P}=0.01,0.002$ and 0.016 , respectively) higher in protein supplemented group compared to the control group (Table 2). This higher body growth in heifer could be narrated due to addition of protein rich ingredients in the concentrate mixer which supported by Strzetelski et al. (2007) who mentioned that increasing dietary energy and protein in the ration of heifer improve WH. Again, highest HG recorded in crossbred heifer by Singh et al. (2015) through feeding concentrate based diet. Time greatly influences on BWG, BLG and HGG of the heifers but the interaction effect of time and diet showed non-significant response on WHG and HGG (Table 3). These finding are supported by Habib et al. (2018) who described that heifers fed green fodder, soybean hay along with mixed concentrate had nonsignificant interaction effect of time and diet on these parameters.

Table 3. Tests of within-subjects effects on DM intake, growth performance and nutritional status parameters

\begin{tabular}{lcc}
\hline Parameters & Source & F-values \\
\hline DMI & Time & $7.54^{* *}$ \\
& Time $\times$ diet & $5.66^{* *}$ \\
BWG & Time & $16.69^{* *}$ \\
& Time $\times$ diet & $4.43^{*}$ \\
WHG & Time & $11.59^{* *}$ \\
& Time $\times$ diet & $2.78^{\mathrm{NS}}$ \\
BLG & Time & $72.45^{* *}$ \\
& Time $\times$ diet & $13.43^{* *}$ \\
HGG & Time & $4.69^{*}$ \\
& Time $\times$ diet & $0.82^{\mathrm{NS}}$ \\
Glucose & Time & $36.62^{* *}$ \\
& Time $\times$ diet & $1.29^{\mathrm{NS}}$ \\
Albumin & Time & $18.7^{* *}$ \\
& Time $\times$ diet & $3.21^{\mathrm{NS}}$ \\
Urea & Time & $9.59^{* *}$ \\
& Time $\times$ diet & $0.76^{\mathrm{NS}}$ \\
Blood urea & Time & $9.54^{* *}$ \\
nitrogen & Time $\times$ diet & $0.75^{\mathrm{NS}}$ \\
\hline
\end{tabular}

DMI, dry matter intake; BWG, body weight gain; WHG, wither height gain; BLG, body length gain; HGG, heart-girth gain. ${ }^{* *}$ Significant at $\mathrm{P}<0.01$, *significant at $\mathrm{P}<0.05$ and NS, non-significant.

\section{Nutritional status}

The data on blood biochemical profile are mentioned in Table 2 and results revealed that blood serum glucose and albumin shows non-significant $(\mathrm{P}=0.493$ and 0.479 , respectively) response through feeding protein supplemented and control diets. Again, tests of withinsubjects indicated that there existed significant $(\mathrm{P}=0.01)$ time effect on serum glucose and albumin of heifers; but the interaction effect of diet and time was nonsignificant $(\mathrm{P}>0.05 ;$ Table 3$)$. However, the blood glucose and albumin concentrations were within the normal levels 2.5-4.16 mmol/L and 3.0-5.0 g/dL, respectively as reported by Kaneko et al. (1997). This finding are closely related to Melvin (1982) who stated that blood glucose and albumin remain same among the dietary groups through supplying energy rich ingredients to the cattle. Albumin is the protein precursor which plays vital role for growth and other physiological purposes; that's the reason to increase protein level in diet for increasing blood serum in animals (Shetaewi and 
Ross, 1991). Albumin level in blood serum reflects the protein availability in the diet and vice-versa which potentially beneficial to the mammals through increasing the available amino acids for absorption (Wada et al., 2017).

Blood urea nitrogen (BUN) and serum urea concentrations of the heifers noticeably significant $(\mathrm{P}=0.015)$ which are presented in Table 2 . With the advancement of feeding time, urea and BUN concentrations increased significantly $(\mathrm{P}=0.01)$. BUN is a metabolic indicator that is being used for assessing the short-term or real-time changes in nutritional profile of animals. Higher urea and BUN found in protein rich ingredients supplemented group that might be increased of $\mathrm{ME}$ and $\mathrm{CP}$ content in the supplied diet. In this study, serum levels of urea and BUN of supplemented groups were 28.05 and $13.10 \mathrm{mg} / \mathrm{dL}$, respectively which are supported by Kaneko et al. (1997). However, Moss and Murray (1992) found higher plasma urea concentration due to supplementary protein intake in heifers. Similarly, Sun and Christopherson (2005) obtained positive relationship between BUN and dietary $\mathrm{CP}$ in ruminants.

\section{Conclusion}

Supplementation of protein rich ingredients (soybean meal and mustard oil cake) in the concentrate mixture of heifers influences dry matter intake and nutritional status. During pre-pubertal period this nutritional status of heifers indicates the impact of such feeding programs for initiating heifer development and replacement. For improving heifer ration quality this findings might have implication in the tropical countries where cattle are often fed rations deficient in protein. It could be concluded that feeding protein rich ingredients with concentrate mixture would effectively improve the growth and nutritional status of the dairy heifers.

\section{Acknowledgement}

The present work was conducted as a part of the BAURES funded project entitled "Supplementation of protein concentrate on the performances of dairy herd replacement stock" (Project Number: 2015/86/BAU).

\section{References}

Alam, M.S., Rashid, M.H., Uddin, M.E. and Asaduzzaman, M., 2012. Effect of supplementation of fish meal on growth and reproductive performance of crossbred heifers. Journal of the Bangladesh Agricultural University, 10: 261-266. https://doi.org/10.3329/jbau.v10i2.14917

Al-Shami, S.A., 2007. Effect of feeding hay supplemented with concentrates on feedlot and reproductive performance of pre-pubertal hassawi heifers. Journal of Animal and Veterinary Advances, 6: 26-28.

AOAC., 2000. Official Methods of Analysis. Association of Official Analytical Chemists, 17th Ed., Arlington, Washington DC.

Ate, I.U., Rekwot, P.I., Nok, A.J. and Tekdek, L.B., 2009. Serum electrolyte values of cows during third trimester of pregnancy and early lactation in settled cattle herds in Zaria, Northern Nigeria. African Journal of biomedical Research, 12: 125-130.

Baker, D.H., 2000. Nutritional constraints to use of soy products by animal. In: J.K. Drackley (ed.) Soy in animal nutrition. Federation Animal Science Society, Savory, IL, USA, pp. $1-12$.

Divya, T. and Anil-kumar D.P., 2009. Effect of different levels of undegradable dietary protein and plane of nutrition on the performance of growing crossbred heifers. Indian Journal of Animal Science, 79: 337-342.

Doyle, P.T., Stockdale, C.R., Ba, N.X. and Van, N.H., 2008. Understanding interactions between forages and concentrates is important for formulating feeding strategies for growing cattle in central Vietnam. Australian Journal of Experimental Agriculture, 48: 821-824. https://doi.org/10.1071/EA07417

Gilbery, T.C., Lardy, G.P., Soto-Navarro, S.A., Bauer, M.L. and Caton, J.S., 2006. Effects of corn condensed distillers solubles supplementation on ruminal fermentation, digestion, and in situ disappearance in steers consuming low-quality hay. Journal of Animal Science, 84: 14681480 . https://doi.org/10.2527/2006.8461468x PMid:16699103

Habib, M.R., Rashid, M.H., Islam, M.A., Majumder, S., Islam, K.M.S., Ahmed, S., Alam M.S. and Vargas-Bello-Pérez, E., 2018. Influence of green grass-based diets on growth and reproductive performance in dairy heifers. Tropical Animal Health and Production, 50: 889-895.

https://doi.org/10.1007/s11250-018-1514-x PMid:29374345

Hammond, A.C., 1997. Update on BUN and MUN as a guide for protein supplementation in cattle. In Proc. Florida Ruminant Nutr. Symp., Univ. Florida, Gainesville. pp. 4352.

Kaneko, J.J., Harvey, J.W., and Bruss, M.L., 1997. Clinical Biochemistry of Domestic Animals. Academic Press, California, USA.

Kearl, L.C., 1982. Nutrient Requirement of Ruminant in Developing Countries. Logan: Utah State University, pp. 117-118.

Khandaker, Z.H., Uddin, M.M., Sultana, M.N., and Peters, K.J., 2012. Effect of supplementation of mustard oil cake on intake, digestibility and microbial protein synthesis of cattle in a straw-based diet in Bangladesh. Tropical Animal Health and Production, 44:791-800. https://doi.org/10.1007/s11250-011-9969-z PMid:21915618

Lanyi, I., 1988: Effect of different planes of protein in fattening of growing bulls. Nutrition Abstract Review, 401.

Melvin, J.S., 1982. Duke's Physiology of Domestic Animals. Ninth edition, Comstock Publishing Associates, A division of Cornell University Press, Ithaca and London. PMCid:PMC1863164

Moss, R.J. and Murray, R.M., 1992. Rearing dairy calves on irrigated tropical pastures. 1. Effect of protein level on live weight gain and blood components. Australian Journal of Experimental Agriculture, 32: 569-579. https://doi.org/10.1071/EA9920581

Peripolli, V., Barcellos, J.O.J., Prates, E.R., McManus, C., Silva, L.P., Stella, L.A., Costa Jr, J.B.G. and Lopes, R.B., 2016. Nutritional value of baled rice straw for ruminant feed. revista brasileira de zootecnia, 45: 392-399.

Prima, N.Z., Khan, M.A.S., Islam, M.A. and Habib, M.R., 2018. Effect of pre- and post-partum concentrate supplementation to crossbred cow on milk yield and quality, calf birth weight and post-partum heat period. Fundamental and Applied Agriculture, 3: 1-7. https://doi.org/10.5455/faa.297521

Seresinhe, T., Pathirana, K.K., 2008. Effect of supplementation of straw based diets on the digestibility and microbial nitrogen production of crossbred cattle. World Journal of Agricultural Sciences, 4: 745-751.

Shetaewi, M. M. and Ross, T.T., 1991. Effects of concentrate supplementation and lasalocid on serum chemistry and hormone profiles in Rambouillet ewes. Small Ruminant Research, 4: 365-377. https://doi.org/10.1016/0921-4488(91)90082-2

Singh, V.P., Dubey, M. and Pandey, R.K., 2015. Effect of different feed combinations on the growth performance of crossbred heifer calves. Asian Journal of Animal Science, 9: 225-232. https://doi.org/10.3923/ajas.2015.225.232

Strzetelski, J., Kowalczyk, J.J. and Bilik, K., 2007. The effect of preand post-pubertal feeding levels on the growth, 
reproduction, and future milk production of Simmental dairy heifers. Journal of Animal Feed Science, 16: 155167. https://doi.org/10.22358/jafs/66735/2007

Sun, S. and Christopherson, R.J., 2005. Urea kinetics in wethers exposed to different ambient temperatures at three dietary levels of crude protein. Asian-Australasian Journal of Animal Sciences, 18: 795-801.

https://doi.org/10.5713/ajas.2005.795

Tegasc, 2014. Replacement heifers-Your dairy cow of the future. In Tegasc Agriculture and Food Development Authority, Lakeland Dairies.

Wada, Y., Takeda, Y., and Kuwahata, M., 2017. Potential role of amino acid/protein nutrition and exercise in serum albumin redox state. Nutrients, 10: 17. https://doi.org/10.3390/nu10010017

PMid:29295548 PMCid:PMC5793245

Wanapat, M. and Pimpa, O., 1999. Effect of ruminal NH3-N levels on ruminal fer-mentation, purine derivatives, digestibility and rice straw intake in swamp buffaloes. Asian-Australasian Journal of Animal Sciences, 12: 904-907. https://doi.org/10.5713/ajas.1999.904

Wiltbank, J. N., Gregory, K. E., Swiger, L.A., Ingalls, J.E., Rothlisberger, J.A. and Koch, R.M., 1966. Effects of heterosis on age and weight at puberty in beef heifers. Journal of Animal Science, 25: 744-751. https://doi.org/10.2527/jas1966.253744x 